\title{
SOCIAL COMMUNICATIONS
}

\section{PUBLIC AND CULTURAL DIPLOMACY AS THE CHANNELS OF EUROPEAN INTEGRATION IDEAS PROMOTION: UKRAINIAN EXPERIENCE}

PhD Student, Tarnavska I. $\boldsymbol{O}$.

Ukraine, Dnipro, Oles Honchar Dnipro National University

DOI: https://doi.org/10.31435/rsglobal_ws/31052019/6523

\section{ARTICLE INFO}

Received: 10 March 2019

Accepted: 06 May 2019

Published: 31 May 2019

\section{KEYWORDS}

public diplomacy, cultural diplomacy, European integration ideas, Ukraine.

\begin{abstract}
The article demonstrates the results of the analysis of the existing approaches to the definition of the "public" and "cultural" diplomacy. Considering the controversial nature of the mentioned definitions, the main principles and practices of public diplomacy, which enable the process of informing, engaging and influencing the international audience by $\mathrm{Ch}$. Ross as well as its structuring factors by J. Nye, are outlined. Ukrainian experience of the usage of public and cultural diplomacy means has been studied in view of their effectiveness in the process of promoting the European integration ideas.
\end{abstract}

Citation: Tarnavska I. O. (2019) Public and Cultural Diplomacy as the Channels of European Integration Ideas Promotion: Ukrainian Experience. World Science. 5(45), Vol.3. doi: 10.31435/rsglobal_ws/31052019/6523

Copyright: (C) 2019 Tarnavska I. O. This is an open-access article distributed under the terms of the Creative Commons Attribution License (CC BY). The use, distribution or reproduction in other forums is permitted, provided the original author(s) or licensor are credited and that the original publication in this journal is cited, in accordance with accepted academic practice. No use, distribution or reproduction is permitted which does not comply with these terms.

Introduction. Public diplomacy is a relatively new concept that emerged in the twentieth century in the USA and it was used to define the process of the communication between the government and society, the dissemination of the latest political messages within the country, and the way of interaction with other countries' citizens (Defining Public Diplomacy, n.d.).

Galion E., introducing the "public diplomacy" term to the general public in 1965, highlighted that this phenomenon "deals with the influence of social attitude on the formation and implementation of the foreign policy. It involves the dimensions of international relations beyond traditional diplomacy..., including the formation of public opinion by the governments worldwide; the interaction of private groups and interests in one country with those in others... and the international flow of information and ideas" (as cited in Валюшко I., 2017: 138).

Some scientists equate public diplomacy with the civic one, while others consider it to be an information and communication technology and an effective way of practical implementation of the country's communication strategies in the international arena. At the same time, whilst public diplomacy influences public opinion, it is not a propaganda as the first is based on an open, objective, genuine exchange and dissemination of information about the country, its values and ideals within the foreign audience.

The objective of the article is to determine the main directions of the promotion of European integration ideas, using the public and cultural diplomacy tools in Ukraine.

Research results. Taking into account the fact that the European values and ideals (the rule of law, respect of human rights, gender equality) are being spread among the Ukrainians in the context of the European integration process implementation, we came to the conclusion that the European Union is pursuing a policy of public diplomacy towards Ukraine, however in the framework of the Eastern Partnership policy, targeting six Eastern European countries (Ukraine, Armenia, Azerbaijan, Belarus, Georgia and the Republic of Moldova). The best example to illustrate this idea is the way of gender equality promotion among Ukrainian society, implemented through various initiatives, namely the 
process of Ukraine's joining the UN Women global campaign "HeForShe" in 2018. The latter involved the conduction of different cultural and art events with a focus on gender issues promotion in a number of cities across Ukraine during a few weeks; introduction of the position of the Governmental Commissioner for Gender Equality Policy for the issue prioritization among the Ukrainian society etc. Overall, all of this distinguishes public diplomacy from PR-activities, because if the latter is usually aimed at promoting the goods or services, public diplomacy's objective is to promote certain intangible values and "public goods".

The majority of researchers point out that while classical state diplomacy involves the maintenance and development of the official relations between countries and communication at the level of the state political elite representatives and diplomats, public diplomacy is intended to provide a dialogue with the public of other countries for the process of their informing about the country, its advantages and features that allows simultaneously to influence the formation of their public opinion. Thus, public diplomacy is a tool for the promotion of the country's interests, influence on the audience abroad (not on the political elite, but on the ordinary citizens of other states) to implement its foreign policy, achieve political and strategic goals.

Researcher Ross Ch. rightly points out that globalization (the integration of human beings, peoples, economies) and the development of information and communication technologies (which unite people from different cultures, nations, countries and continents) are important factors and characteristics of the current international environment, in which the communication and dialogue in the framework of international relations take place. Although, while political decisions are also being discussed and adopted in the narrow circle of diplomats and high-level officials, their effective implementation in the 21st century is impossible without society engagement into this process. At the same time, Ross Ch. highlights that to influence the public opinion abroad, it is necessary to start with its own society. In this context, the researcher identifies seven pillars of public diplomacy, namely principles and practices that promote informing, involvement and impact on the international audience (primarily the public, not high-ranking officials). The first principle is related to the "public advocacy" and public diplomacy measures, aimed at promoting and protecting the country's national interests worldwide, and enabling its international obligations fulfillment. At the same time, the first and most important element hereof is the explanation of the country's policy, its priorities and goals among the international audience. This requires the development and implementation of a country's communication or information strategy with well-defined priorities, clear messages, effective resources and promotional channels for specific target audiences, involving the use of different formats, language, tools etc. The second principle should enable the explanation of the reasons and justification for the country's policy, along with the provision of an understanding of the country's political context, based on its cultural and value principles, and in case of the country's participation, for example, in the process of international conflicts or crises resolution, public diplomacy is regarded as an efficient instrument of public understanding of the country's position, its priorities and reasons behind some political decisions (Ross, 2003).

In this context Ross also provides a special role to stereotypes about the country, so they should be considered during the process of development of certain strategic information and communication documents and conduction of public diplomacy. As representatives of foreign civil society generate their assessments and judgments, based on a set of well-known characteristics and facts about the country, therefore public diplomacy is aimed to either confirm their assumptions or refute them (Ross, 2003).

The third principle is the necessity to formulate a clear, truthful and reliable public message (based on the analysis and selection of topics and problems, requiring public disclosure in the eyes of the world community), while it is important to divide the target audience into groups and formulate separate message for each of them, which will transmit the same idea whilst using different language, format, style, visuals and other technical characteristics. It is vital to note that researchers also underline the necessity to "test" the message among target audiences before its distribution to determine the level of its impact, effectiveness and necessity of its adjustment. This feature is determined by the fourth principle. At the same time, the efficiency of a political message is as an important characteristic of the modern world as its preciousness, according to Ross $\mathrm{Ch}$., because, if the information about the country does not systematically appear in the international information space, this niche can be replaced by other information, which can carry false facts (misinformation), incorrect view or provide the explanation of the country's situation in such a way that can negatively affect or destroy the image of the country in the eyes of the global community. Consequently, every country should systematically work and be present in the global information space with its information, especially considering the opportunities, provided by the Internet, social networks and other modern information and communication technologies (Ross, 2003). 
The fifth principle concerns the necessity for regular broadcasting of the key political messages to the internal and external audiences through national and international media, including not only traditional print and audiovisual media, but also Internet communications (social networks, online newspapers, mailing lists), conduction of events for media representatives, press tours, educational and cultural exchanges etc. According to the majority of researchers, a significant role in this case belongs to television with its superiority and the ability to transmit visual content, allowing for spread and any interpretation of the news (same events can be covered differently - positively, negatively, reliably or falsely) (Ross, 2003).

The next principle emphasizes partnership to be an important element, which involves the necessity to engage partners into the process of public diplomacy - business, international, humanitarian and non-governmental organizations, civil society, diaspora representatives and other actors who, in their turn, has the opportunity to disseminate information, promote the country, its values and culture among various target audiences, namely: representatives of the diaspora - among their circle of friends abroad, business - among their foreign partners etc. (Ross, 2003).

The last point is dedicated to the dialogue that should be carried out at the following level: the country has to listen to the international community while expressing its "own thoughts/views" through communication, since the lack of desire to listen and communicate with the external world could lead to more negative stereotypes about the state and badly affect its image. The researcher suggests conducting the outlined dialogue at the level of communication between citizens of different countries through their participation in exchange programs (for journalists, artists, scientists, students, youth etc.), allowing for certain stereotypes about the country and its citizens to be destroyed - this will contribute to the development of multiculturalism and the establishment of effective global dialogue and communication (Ross, 2003).

The similar views on public diplomacy also express J. Nye, however, he focuses on the three dimensions of the concept:

1) daily communication, which includes clarification of the context of certain political decisions taken in the area of home and foreign policy. At the same time, country officials, after having made some decisions, generally disseminate this information among national media, however, according to the scholar, it is also important to inform the foreign media about strategically important events and political decisions;

2) strategic communications that include a range of topics and messages, distributed among the national and global audiences;

3) the establishment and development of partnerships at an inter-community level, including participation of civil society at international exchanges, seminars, trainings, conferences and other similar events (Nye, 2004).

The main tools of public diplomacy are the conduction of joint public events and information campaigns abroad, the organization of exchange programs (for youth, students, civil servants, academics and other society groups) and language trainings, media materials distribution (via television, radio, print media and the Internet) etc.

In 2015, a new structural unit - the Office of Public Diplomacy - was opened within the Ministry of Foreign Affairs of Ukraine. It is aimed at promoting the development of relations with the public, civil associations, international and national media; implementing the image, cultural and informational projects of Ukraine abroad; coordinating the activities of other executive bodies in these areas for the promotion of Ukrainian interests abroad and for the interaction with the general public.

Thus, while classical diplomacy enables dialogue at a high political level (between presidents, prime ministers, and ministers), public diplomacy enables communication at a lower level and helps reach different target audiences abroad, including citizens, public organizations, businesses, educational institutions etc. So, we came to the conclusion that public diplomacy is a way of communication between the government and foreign society with an aim of influencing the latter, its public opinion and develop a positive image of the country in the eyes of the mass foreign audience, rather than within the political elite. The tools of public diplomacy include mass media, the organization of information and awarenessraising campaigns, events. We consider public diplomacy to be an efficient way of contribution to the achievement of the country's political goals by "soft means".

One of the components of the public diplomacy, which some scholars define as a separate form of diplomacy, while others emphasize on the necessity of its consideration under the public diplomacy concept, is the cultural diplomacy. 
This phenomenon is relatively new in the field of national science, so the vast majority of studies of this term belong to foreign authors. However, the concept becomes of significant importance in the context of the implementation of the European integration course of Ukraine and the opposition to the hybrid war.

According to G. Lutsyshyn and A. Goncharuk, cultural diplomacy is a type of modern diplomacy and an effective mean of realization of political, economic, social, cultural and other vectors of country's development, as it enables the dissemination of information about the state through the organization and conduction of cultural, educational and art events, popularization of the history, language, culture of the state among the global community (Lutsyshyn \& Goncharuk, 2017). M. Protsyuk considers cultural diplomacy as a tool of "soft power", which should become an element of state policy through its ability to provide solutions to the issues of national security, promote the formation of a positive image of the country and interethnic dialogue (Protsyuk, 2016). Thus, cultural diplomacy is a concept that includes aspects of the country's image formation, its interests' promotion, popularization of its culture, history, and values among the international community by cultural means.

The internal dimension of cultural diplomacy (the state domestic cultural policy) contributes to the creation of a unique cultural product that reflects the peculiarities, unique cultural codes of the state and its people, and by these means influences its quality and peculiarities of the retranslation in foreign political discourse. At the same time, in Ukraine there is a problem of lack of resources (financial, personnel and others), policy of popularization and state support of cultural initiatives.

One of the most successful practices in the implementation of the cultural diplomacy policy at an international level, namely the promotion and awareness-raising about the country's culture, history, language in the international relations area, is the issue of its institutional support, involving the functioning of cultural institutions of a certain country abroad. Some European countries have an extensive system of cultural institutions, such as the British Council (Great Britain), the GoetheInstitut (Germany), the French Institute and the Alliance Française (France), the America House (US), the Polish Institute (Poland) etc. - all of them have their representations in Ukraine. These institutions are intended to provide intercultural communication and promote the values and interests of the country in the foreign policy dimension.

In this context, Rozumna O. P. highlights the global trends in the cultural institutions functioning: state support (the country is interested in these institutions through their ability to promote its foreign policy interests); subordination to diplomatic institutions (foreign ministries, embassies etc.); provision of language learning services (language courses at a cultural institute, such as the possibility of studying French at the French Institute or Alliance Française, the German - at the Goethe-Institut etc.); the spread of values through the implementation of projects, the organization of festivals, events, the days or the years of languages (in particular, the British Council, the French Institute, the Goethe-Institut promote the European values in Ukraine. The French Institute regularly holds the annual French Spring, and with the diplomatic missions of other French-speaking countries The Days of Francophonie in Ukraine. These initiatives include the conduction of dozens of arts, literature, music, cinema, theater events. Since 2016, the program for popularization of the study of foreign languages has been implemented in Ukraine, therefore, 2016 was announced as the year of the English Language, 2017-2018 academic year - the year of the German Language, 2018-2019 academic year is the year of the French Language); establishment of bilateral partnerships and cooperation (support and organization of joint initiatives by the representative and host countries); contemporary art support; a network structure (headquarters - representations in different countries - a system of regional offices) (Розумна, 2016).

Since the proclamation of the independence, cultural diplomacy in Ukraine has been implemented at the level of individual initiatives, projects, events realization or participation in international art events abroad. In particular, in 2012-2013, Ukraine organized an exhibition of works of a famous sculptor Pinzel in the Louvre museum, in addition, the country annually participates in the Frankfurt Book Fair. However, this activity is not systematic, clearly planned and strategically defined (included into the national official governmental plans and strategies), therefore it does not contribute to a full understanding of the cultural heritage, history, values of Ukraine by the international community, and also does not have the proper institutional support. According to most researchers, an effective solution is an institutional support of this sphere, and it is important to note that since the beginning of the 2000s, the issue of necessity to provide institutional support of cultural policy and the cultural diplomacy implementation was actualized in the country. As a result, the first step featured the creation of cultural and information centers at the embassies of Ukraine abroad, in accordance with the 
Presidential Decree No.142/2006 as of February 20, 2006 "On the Cultural and Information Center within the Foreign Diplomatic Mission of Ukraine". The purpose of these centers involved the development of international cooperation in the cultural, educational, touristic, sports spheres; dissemination of information about Ukraine, in particular regular news; promotion of history, culture, language; maintenance of contacts with Ukrainianian diasporas (Про культурно-інформаційний центр у складі закордонної дипломатичної установи України, 2006). However, according to expert opinion, these activities were not highly effective and did not lead to achievement of progress in the popularization of Ukraine's culture across the globe. In addition, the government took initiatives to introduce other cultural institutions, in particular the State Agency for Promotion of Ukrainian Culture, but they were not also of great success.

The events of the Revolution of Dignity, Euromaidan, the conflict in the East of Ukraine, the need to opposition to the hybrid war and the implementation of the European integration course contributed to the actualization of the issue of the formation of an effective system of cultural diplomacy and its institutional support for accelerating Ukraine's interests promotion in the world, its emergence in the international information and cultural environments, as well as to its clear positioning as a country with the European values. However, these elements require intensive work and joint efforts both from the government and the society. It is essential to remind that some initiatives have currently been launched to popularize Ukrainian socio-political and cultural issues, they are mainly taken so far by Ukrainian activists, young people, cultural actors who know foreign languages, who are open to intercultural communication, and strongly support European values. In particular, some volunteer activities, events and projects have been implemented abroad without any state support and participation, namely: one of the most striking examples is the implementation of the initiative by a group of Ukrainian activists, who visited a number of Dutch cities before the referendum in the Netherlands, dedicated to the support or denial of the Association Agreement between Ukraine and the EU in 2016, to convince Dutch citizens of the necessity to support this document and of its importance for Ukraine. This initiative shows the role of civil society in the achievement of country's domestic and foreign policy goals. The "diplomats" of Ukrainian culture in the world are Ukrainian artist and director Vladislav Troitsky and art curator Pavel Gudimov. V. Troitsky founded the Kyiv Center of Contemporary Art "DAKH" in 1994, which, in addition to theatrical productions, introduces the Ukrainian music to the international audience through the organization of concerts of the well-known in Europe groups "DahaBraha", Dakh Daughters (contemporary Ukrainian music using national folklore motifs) and the young musical group "TseSho", the texts of the latter group are based on the up-to-date Ukrainian news (socio-political situation in the state). Pavel Gudimov, being a former member of the Okean Elzy group, is currently engaged into the implementation and promotion of Ukrainian cultural projects in the world, in particular: in 2007, the activist established the art gallery "I Gallery" to popularize contemporary art and is currently engaged into both the development of culture at the level in Ukraine through lectures, discussions, workshops, round tables, the implementation of museum projects within the state, and in the external discourse - the organization of exhibitions of Ukrainian artists abroad and the promotion of Ukrainian cultural products among the international community. In addition, on the initiative of sisters Natalia and Olga Pasichnyk, who are based in Sweden, a non-governmental institution "Ukrainian Institute in Sweden" (www.ukrainskainstitutet.se) was established in 2014 to promote Ukrainian culture (cinema, art, literature, music, language etc.) in the EU, spread objective information about Ukraine among Swedish population, form a positive image of Ukraine abroad through organization of artistic and charitable events.

On April 2019 a summary of the National Institute for Strategic Studies "The Priorities for Ensuring the Humanitarian Presence of Ukraine in the World" was published. It focuses on the necessity of carrying out the systematic deployment of humanitarian diplomacy, "including not only cultural and educational diplomacy, international presentation of history, but also scientific and technical diplomacy ... Ukrainians should be associated among the foreign community with not only certain historical achievements of the past, but also with the achievements of the present - the solution of complex scientific tasks (for example, the mathematical tasks on the densest packaging of bullets in 8 and 24-dimensional spaces using modular forms, solved by M. Vyazovska), successes in the scientific Olympiads (International Mathematical Olympiad-2017, Queen's International Innovation Challenge-2017, Robot Launch-2017, Infomatrix-2018, Beijing Youth Science Creation Competition-2018, the European Mathematical Olympiad-2018 for girls), the authorship of videogames (such as STALKER, Cossacs, World of Warplanes, Venom. Codename: Outbreak, Warface, Cryostasis) and startups (PassivDom, Petcube, 
Cardiomo, Effa, SolarGaps, Senstone, Flasty etc.)," which is stated in the document (Пріоритети забезпечення гуманітарної присутності України в світі: резюме, 2019).

Thus, after considering the individual initiatives of civil society and activists, it is important to stress that this activity requires active involvement of the state in this process, that includes the provision of adequate institutional support, strategic planning and effective practical implementation.

With the signing of the EU-Ukraine Association Agreement, some progress has been made on this path, namely: discussions about the necessity of carrying out public and cultural diplomacy at the state level with the involvement of relevant specialized bodies were established and led to the creation of the Department of Public Diplomacy in the Ministry of Foreign Affairs in 2015, including the Department of Cultural Diplomacy as a separate unit. Another issue, which is of utmost importance, was the creation of a Ukrainian Institute - an institution, aimed at promoting Ukrainian culture and the country's image by cultural diplomacy means, with the active participation and support of the activities of the Ministry of Foreign Affairs of Ukraine and the Ministry of Culture of Ukraine. In 2017, the Cabinet of Ministers issued a decree No. 430-r from June 21, 2017, "On the Establishment of a State Institution "Ukrainian Institute". The institution has been operational since 2018. The main results of its activities have regularly been presented on its official website http://ui.org.ua. In this context, it is important to study some features of the functioning of this cultural facility according to its Charter.

State Facility "The Ukrainian Institute", or shortened UI, is aimed to provide a comprehensive presentation of Ukraine in the world to improve the level of understanding and perception of the country in the international arena and contribute to the formation of a positive image of Ukraine abroad. The main tasks of the Institute include the increase in the recognition of Ukraine abroad; development of international dialogue through participation in international art projects etc.; exchange of experience in the field of civil society development, promotion of values; popularization of the Ukrainian language and culture. These tasks are planned to be carried out by the following means: regular presentations of Ukraine abroad, organization and conduction of events on informing about the social, political and cultural issues in Ukraine among the international community; development and distribution of Ukrainian cultural product globally (printed, audiovisual and various new forms - videos, blogs, leaflets, films); participation in international cultural and socio-political events; organization of joint events, international exchanges between Ukrainian and foreign experts, journalists, youth, and the public; implementation of joint intercultural projects, establishment of international cooperation; popularization of Ukrainian language and literature abroad, its translations into foreign languages. It is vital to add that the control over the activities of the Institution will be assigned to the Supervisory Board, and funding will be provided by the country, charitable contributions and donor assistance (About the Establishment of the State Institution "Ukrainian Institute", 2017).

In our opinion, this institution will become an effective element of the system of cultural diplomacy and will help promote the interests of Ukraine in the world, contribute to solution of certain political issues, establishment and maintenance of cooperation, and conduction of political dialogue with the international community, formation of a positive image of Ukraine globally. Although all of these outlined tasks, functions and goals of this institution are currently theoretical, and the effectiveness of their implementation will depend on the expediency and the quality of planning and practical steps for their implementation may take more than one year. Moreover, the lack of legislative regulation of certain issues, the imperfection of the mechanism of cooperation and interaction between authorities, the low involvement of the expert community and the public into the issue of creation and participation in the Institute activities, the need to develop an effective mechanism for strategic management and cultural marketing of the institution etc., are significant constraints on the path of productive functioning of the "cultural body". It is essential to add that the Ukrainian Institute is also aimed to help introduce European practices into Ukrainian culture and promote European integration of Ukraine within the global cultural space.

Conclusions. Thus, public, and its type - cultural, diplomacy, is an important element and instrument of the implementation of European integration policy of Ukraine, but the analysis allows us to conclude that it is implemented more at the level of realization of private initiatives by civil society representatives and activists, and not at the state level which can be explained by the lack of resources, the bureaucracy of certain procedures, which serve as a significant obstacle to the process of building an effective institutional model of cultural diplomacy in Ukraine.

It is important to highlight that in the absence of a clear national information policy, citizens abroad perceive Ukraine primarily as a large country, which border with the EU member states, has a high level of corruption, a weak economy, political instability and a continuing conflict in the East, 
respectively, as notes the famous Ukrainian writer Serhiy Zhadan, in the lack of objective and regular information about Ukraine in the international information space, the global community will automatically perceive any information about Ukraine (true or false) as credible and thus form such a view about the state. Thus, civil diplomacy as a kind of "soft power" is an effective tool on the way of changing the attitude and representation of the global community about Ukraine and the formation of its positive image in the eyes of foreign citizens.

\section{REFERENCES}

1. Defining Public Diplomacy (n. d.). University of Southern Carolina. Retrieved from: https://uscpublicdiplomacy.org/page/what-pd.

2. Nye J. (2004). Public Diplomacy in the 21st Century. What factors need to be considered to explain U.S. policy to audiences abroad? May 10. Retrieved from: https://www.theglobalist.com/public-diplomacy-inthe-21st-century.

3. Ross Ch. (2003). Pillars of public diplomacy. Harvard International Review. Vol. 25. № 2. P. 22. Retrieved from: http://hir.harvard.edu/article/?a=1117.

4. Валюшко I. (2017). Дипломатія України у вимірі інформаційної безпеки країни. Вісник Львівського університету. Серія філос.-політолог. студії. Вип. 13. С. 137-142.

5. Луцишин Г., Гончарук А. (2017). Особливості розвитку культурної дипломатії України в сучасних умовах. Humanitarian Vision. Vol. 3. No 1. P. 25-30. Retrieved from: http://ena.lp.edu.ua:8080/bitstream/ntb/39956/2/2017v3n1_Lutsyshyn_HPeculiarities_of_the_development_25-30.pdf.

6. Пріоритети забезпечення гуманітарної присутності України в світі: резюме (2019.). Retrieved from: http://www.niss.gov.ua/doslidzhennya/analitichni-materiali/gumanitarniy-rozvitok/prioritetizabezpechennya-gumanitarnoi.

7. Про утворення державної установи "Український інститут”: Розпорядження КМУ від 21 червня 2017 p. № 430-p. (2017). Retrieved from: https://www.kmu.gov.ua/ua/npas/250094619.

8. Процюк М. В. (2016). Публічна та культурна дипломатія як засіб «м'якої сили» України: запозичені моделі, реальні кроки та стратегічні пріоритети. Науковий вісник Дипломатичної академії Украӥни. №. 23 (2). C. 21-28. Retrieved from: http://www.irbis-nbuv.gov.ua/cgibin/irbis_nbuv/cgiirbis_64.exe?C21COM=2\&I21DBN=UJRN\&P21DBN=UJRN\&IMAGE_FILE_DOWN LOAD $=1 \&$ Image_file_name=PDF/Nvdau_2016_23(2)_5.pdf.

9. Розумна О. П. (2016). Культурна дипломатія України: стан, проблеми, перспективи. Retrieved from: http://www.niss.gov.ua/content/articles/files/kultu_dypl-26841.pdf. 